\title{
Preparation of Tritium Standard Gas by the Use of Tritiated Methane
}

\author{
Kouhei Kushita, Norio TAKEUCHI and Kiyoshi HoIzUMI \\ Radioisotope Center, Japan Atomic Energy Research Institute \\ Tokai-mura, Ibaraki Pref. 319-11, Japan \\ Received September 11, 1984
}

\begin{abstract}
Tritium standard gas for calibrating radioactivity detectors was prepared by the use of tritiated methane synthesized by the reaction of tritiated water with aluminum carbide at ca. $470^{\circ} \mathrm{C}$. A long-path proportional counter was used to standardize the radioactivity of the prepared gas. Tritiated gas of less than $10^{4} \mathrm{~Bq}$ could be measured by this counter with the overall error of $3.5 \%(3 \sigma)$. Finally, two types of standard were prepared in a metal cylinder and a glass ampoule. The latter type could be used as a handy calibration source for detectors.
\end{abstract}

Key Words: tritium, radioactive standard, tritiated methane

\section{Introduction}

A great number of studies on tritium have been made from various standpoints, especially in connection with the development of fusion reactors. For the measurement of the radioactivity of gaseous tritium, proportional counters and ionization chambers are often employed. Tritium standard gases commercially available from several suppliers are used for the calibration of those apparatuses. These standards, however, are not always satisfactory in the accuracy of radioactivity (e.g. 3 to $10 \%$ uncertainty) and are somewhat expensive in spite of the short period to be guaranteed for the use (e.g. 4 months). For periodic calibrations of detectors of tritium, Yoshida, et al. ${ }^{1)}$ prepared secondary standard gases of tritium from primary standards purchased from a foreign supplier.

The authors have attempted to prepare a primary tritium standard gas with good accuracy and of convenience to calibrate detectors. Tritiated methane was employed as a standard gas $^{2)}$ because permeation through and adsorption on a container wall are less effective for methane than for tritium gas (HT, $\left.\mathrm{T}_{2}\right)$. Tritiated methane was synthesized by the reaction of tritiated water with aluminum carbide. The optimum reaction temperature for the production of radiochemically pure tritiated methane was examined. To standardize the radioactivity of tritiated gas prepared by this work, a long-path proportional counter developed ${ }^{3}$ by the authors was employed.

\section{Experimental}

2.1 Synthesis of tritiated methane

\subsubsection{Materials}

Aluminum carbide $\left(\mathrm{Al}_{4} \mathrm{C}_{3}\right.$, $\geqq 98 \%$ in purity, 325 mesh) purchased from Mitsuwa Chemicals Co., Ltd. was used without further purification. Tritiated water (ca. $0.4 \mathrm{MBq} \mathrm{m} l^{-1}$ ) was supplied from a stock solution which was generated as a waste solution of tritium production experiments in the authors' laboratory ${ }^{4}$. To synthesize the tritiated methane of a relatively high specific radioactivity, tritiated water with nominal specific activity of $195 \mathrm{GBq} \mathrm{m} l^{-1}$ was obtained from Amersham International plc, England, and was used after dilution procedures to get proper concentrations. Helium $(99.9999 \%)$ and $\mathrm{N}_{2}(99.999 \%)$ gases, which came from Nippon Sanso Co., Ltd. and Hitachi Sanso Co., Ltd. respectively, were used as carriers without further purification.

2.1.2 Apparatus and procedures

The apparatus used for the synthesis of tritiated methane is illustrated in Fig. 1. Tritiated water was injected with a micro syringe (A) through a silicone packing into the reaction column $(15 \mathrm{~mm} \phi \times 200 \mathrm{~mm}$; B) of quartz glass 


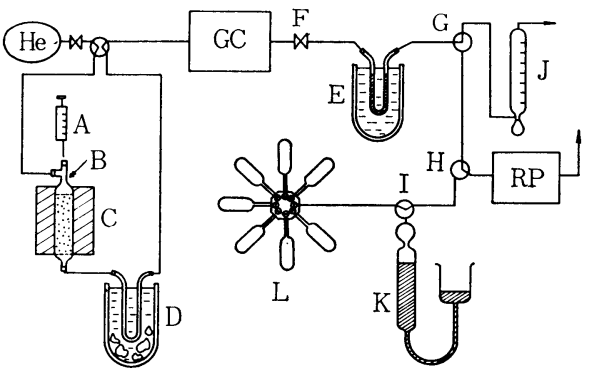

A: Micro syringe, B: Reaction column, C: Electric furnace, D: Cold trap $\left(-72^{\circ} \mathrm{C}\right)$, E: Cold trap $\left(-196^{\circ} \mathrm{C}\right), \mathrm{F}$ : Stop cock, G, H, I: Three-way cock, $\mathrm{J}$ : Flowmeter, K: Toepler pump, L: Ampoule system

Fig. 1 Schematic diagram of the apparatus used for the synthesis and distribution of tritiated methane.

packed with the mixture of aluminum carbide $\left(\mathrm{Al}_{4} \mathrm{C}_{3}\right.$, ca. $\left.2 \mathrm{~g}\right)$ and quartz wool. The reaction products were led with $\mathrm{He}$ carrier gas through a cold trap (D) cooled at $-72^{\circ} \mathrm{C}$, in which unreacted tritiated water was collected, to a gas-chromatograph in order to measure the amount of synthesized methane. The gaschromatograph (Shimazu GC-6AM) was equipped with a thermal conductivity detector and a column $(4 \mathrm{~mm} \phi \times 2 \mathrm{~m})$ packed with activated carbon $(30 / 60 \mathrm{mesh})$. Temperature of the column was kept at $100^{\circ} \mathrm{C}$. The gaseous products were finally collected in a silica gelcontaining cold trap (E) chilled at $-196^{\circ} \mathrm{C}$.

After a desired amount of tritiated methane had been collected in the trap (E), a stopcock (F) was closed and a three-way cock (G) was turned to connect the trap (E) to a rotary pump. The $\mathrm{He}$ carrier gas was removed from the trap (E) by evacuation for more than 10 min. Turning the three-way cock $(H)$, the trap (E) was then warmed up to an ambient temperature. The retaining methane in the trap was evaporated by this treatment and transferred with the aid of a Toepler pump (K) to the ampoule system (L) which was evacuated in advance. The ampoule system was equipped with stopcocks for each glass ampoule (2 to $10 \mathrm{ml}$ in volume). These stopcocks were closed before the ampoules filled with tritiated methane were fuse-sealed off. By this operation, scatterings of the amount of the sealed gas per unit volume of the ampoules were reduced.
In general, the reaction of aluminum carbide with water is expressed in the equation

$\mathrm{Al}_{4} \mathrm{C}_{3}+12 \mathrm{H}_{2} \mathrm{O} \rightarrow 4 \mathrm{Al}(\mathrm{OH})_{3}+3 \mathrm{CH}_{4}$,

where half of the hydrogen atoms in the water (tritium atoms when tritiated water was used) is transformed into methane. And it takes a few hours to complete this reaction at relatively low temperatures $\left(100-200^{\circ} \mathrm{C}\right)$ because of its moderate reactivity ${ }^{5), 6)}$. On the other hand, aluminum hydroxide produces water by thermal decomposition at higher temperatures $\left(>300^{\circ} \mathrm{C}\right)$;

$$
2 \mathrm{Al}(\mathrm{OH})_{3} \rightarrow \mathrm{Al}_{2} \mathrm{O}_{3}+3 \mathrm{H}_{2} \mathrm{O} \text {. }
$$

Therefore, the reaction

$$
\mathrm{Al}_{4} \mathrm{C}_{3}+6 \mathrm{H}_{2} \mathrm{O} \rightarrow 2 \mathrm{Al}_{2} \mathrm{O}_{3}+3 \mathrm{CH}_{4},
$$

which has been derived from the equations (1) and (2), can be expected at higher temperatures $\left(>300^{\circ} \mathrm{C}\right)$. In this case, hydrogen (tritium) will be transformed into methane efficiently and the reaction time can be reduced at the same time. To examine these advantages, temperature effect of this reaction was investigated at first.

Water $\left(\mathrm{H}_{2} \mathrm{O}, 3 \mu l\right)$ was injected into the reaction column at various temperatures, while the flow rate of $\mathrm{He}$ carrier gas was adjusted at $15 \mathrm{ml} \mathrm{min}{ }^{-1}$. Effect of the flow rate on the yield of methane, on the other hand, had been surveyed from $0 \mathrm{ml} \mathrm{min}{ }^{-1}$ (water being kept in the reaction column for a few minutes) to $30 \mathrm{ml}$ $\min ^{-1}$ in advance. This effect, however, proved

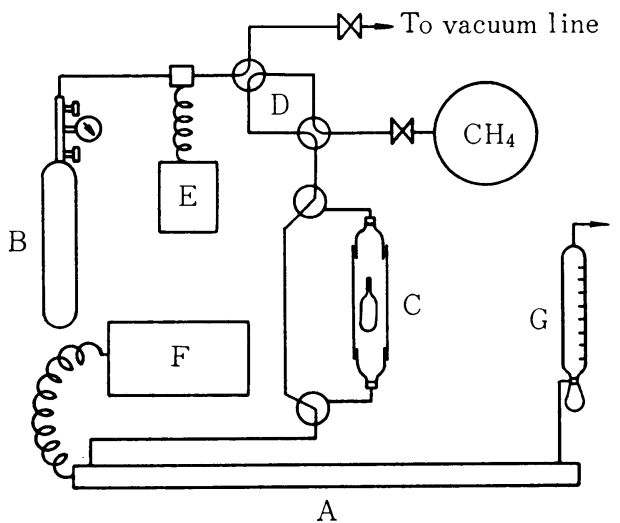

A : Long-path proportional counter, B: Standard gas cylinder, C: Ampoule breaker, D: Sampler, E: Pressure gauge, F: Counting system, G: Flowmeter

Fig. 2 Schematic diagram of the apparatus used for the standardization of tritiated gas prepared by this work. 
to be of less importance compared with the temperature effect. Accordingly, $\mathrm{He}$ carrier gas was controlled to flow at $15 \mathrm{ml} \mathrm{min} \mathrm{m}^{-1}$ afterwards.

\subsection{Measurement of radioactivity}

Radioactivity of the tritiated gas was measured with a long-path proportional counter ${ }^{3)}$. Figure 2 shows a setup of the counting system. The long-path proportional counter (A) made from stainless steel tube of $1000 \mathrm{~mm}$ long and 21.3 $\mathrm{mm}$ i.d. was coupled with a gas handling system. As an anode of the counter, a $50 \mu \mathrm{m} \phi$ tungsten wire was stretched in the center of the tube. The operation voltage was $3200 \mathrm{~V}$. The aliquot of sample gas in the cylinder (B) was introduced into the sampler (D) whose volume was precisely known. Temperature and pressure of the gas were measured simultaneously. The sample gas was then transferred with counting gas (pure methane) into the counter (A). Counting was carried out while the sample gas was moving through the counter tube together with the counting gas at the flow rate of $30 \mathrm{ml}$ $\min ^{-1}$.

For the measurement of radioactivity of tritium in a sealed ampoule, the ampoule was broken in the ampoule breaker (C) in the atmosphere of methane counting gas and the released gas was introduced into the counter (A). Counting was performed in the same way as described above.

\section{Results and Discussion}

3.1 Synthesis of tritiated methane

3.1.1 Effect of reaction temperature

The temperature effect on the yield of

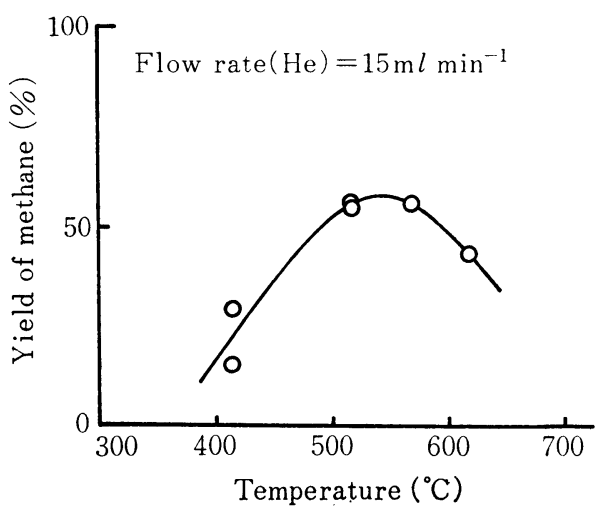

Fig. 3 Temperature effect on the yield of methane.

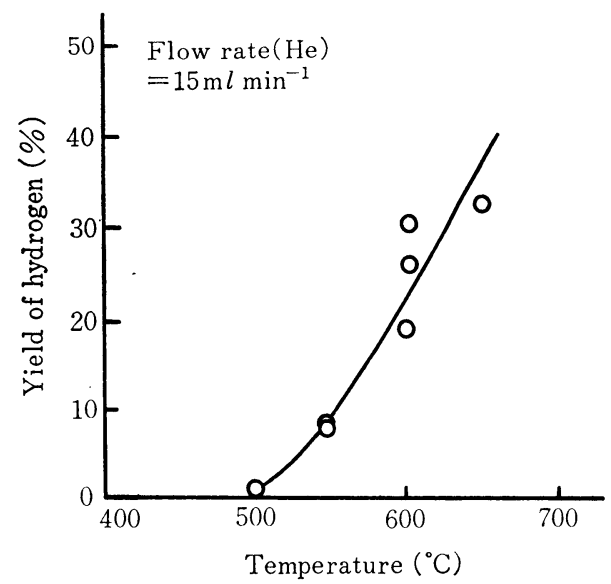

Fig. 4 Temperature effect on the yield of hydrogen. methane was measured by a gas chromatograph, and shown in Fig. 3. The amount of methane synthesized was very small at temperatures below $400^{\circ} \mathrm{C}$. The maximum yield of methane was obtained at 520 to $560^{\circ} \mathrm{C}$ and the yield of methane decreased gradually beyond ca. $560^{\circ} \mathrm{C}$.

Radio-gas chromatographic assay of tritiated methane synthesized at $520^{\circ} \mathrm{C}$ revealed the presence of HT in the product. Temperature dependency on the production of hydrogen was then investigated. As seen in Fig. 4, a rapid increase in hydrogen generation was observed above $500^{\circ} \mathrm{C}$. The decrease in the yield of methane at temperatures above ca. $560^{\circ} \mathrm{C}$ could be explained by the generation of hydrogen as a by-product. The presence of HT in a tritium standard gas seemed to reduce the accuracy of the radioactivity value because of the permea-

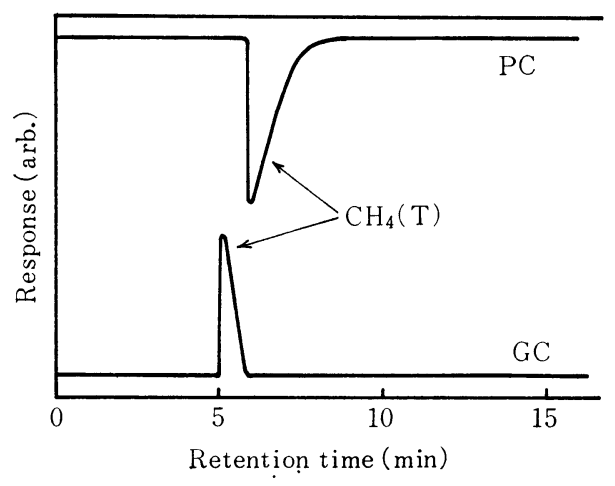

PC: Obtained by using a proportional counter.

GC: Obtained by using a gas chromatograph.

Fig. 5 Radio-gas chromatogram of tritiated methane synthesized at $470^{\circ} \mathrm{C}$. 


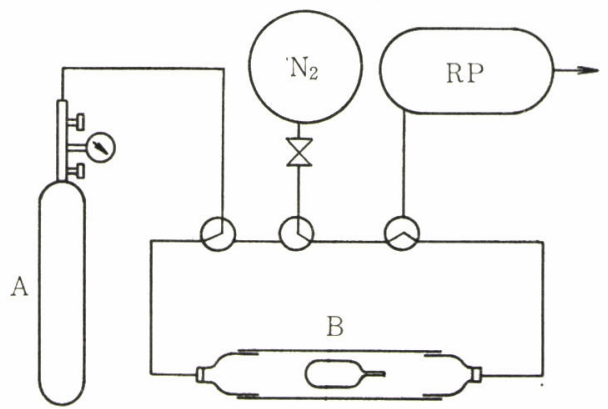

A : Standard gas cylinder B : Ampoule breaker Fig. 6 Schematic diagram of the apparatus used for the preparation of cylinder-type standard gas by compressing tritiated methane with $\mathrm{N}_{2}$ carrier gas.

bility or the adsorptive property of hydrogen (tritium). Considering these effects, methane was synthesized at a little below temperature of $500^{\circ} \mathrm{C}$ to avoid the generation of HT.

Radio-gas chromatographic assay proved that the tritiated methane prepared by this method at $470^{\circ} \mathrm{C}$ was radiochemically pure, HT fraction being under the detection limit, as shown in Fig. 5. Isotopic analysis was not performed but the product could be considered to be monotritiated, since the $\mathrm{T} / \mathrm{H}$ ratio of the tritiated water used was very small $\left(3.6 \times 10^{-9}\right)$.

\subsubsection{Preparation of tritium standard gas}

For the use of a standard gas, the tritiated methane in glass ampoules was finally transferred into a stainless steel cylinder $(500 \mathrm{ml})$ with $\mathrm{N}_{2}$ carrier gas under a pressure of around $9 \mathrm{~kg} \mathrm{~cm}^{-2}$. Tritiated methane of relatively high specific radioactivity (e.g. $80 \mathrm{kBq} \mathrm{m}^{-1}$ ) was prepared for this purpose. As illustrated in Fig. 6, the cylinder was equipped with a bellows valve, a pressure gauge, and a stop valve.

As a handy tritium standard, the gas was also filled in glass ampoules. To calibrate detectors with such a type of standard, the glass ampoule is broken in a stream of carrier gas and all the inner gas is allowed to flow into the detector. Photo 1 shows an example of an ampoule breaker and an ampoule. Then, a troublesome procedure of sampling the aliquot of standard gas with precise measurements of volume, temperature, and pressure of the gas is not needed for the ampoule-type standard. Tritiated methane in ampoules was assayed with the radio-gas

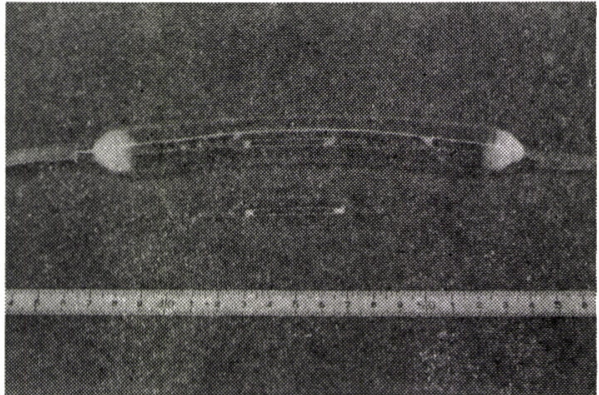

Photo 1 An example of an ampoule breaker for an ampoule-type tritium standard gas. The main part of the ampoule breaker is made of vinyl resin tube, in which a glass ampoule is broken to release the inner gas.

Table 1 Distribution of tritiated methane per unit volume of the ampoules of the same batch

Ampoule Ampoule Radioactivity Volumetric activity

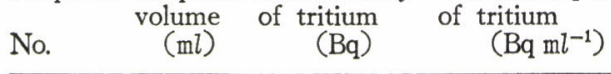

\begin{tabular}{llll}
\hline 1 & 4.828 & 729 & 151 \\
2 & 4.907 & 746 & 152 \\
3 & 4.908 & 741 & 151 \\
4 & 4.915 & 752 & 153 \\
5 & 5.027 & 759 & 151 \\
\hline
\end{tabular}

Average $152 \pm 2.7(3 \sigma)$

$( \pm 1.8 \%)$

chromatograph to examine the scattering of the amount of tritiated methane per unit volume of the ampoules of the same batch. Table 1 shows the result. The scattering was $1.8 \% \quad(3 \sigma)$. Consequently, the activities of tritium sealed in ampoules can be calculated from the ampoule volumes with the error due to sealing process of $1.8 \%(3 \sigma)$ by means of activity measurements of sealed gas in several ampoules of the same batch.

\section{$3 \cdot 2$ Measurement of radioactivity}

The sample gas is supplied to the inlet from the sampler or the ampoule breaker and flows slowly at the linear velocity of ca. $80 \mathrm{~mm} \mathrm{~min}^{-1}$ in the long-path proportional counter tube. The typical response curve obtained by this counter is shown in Fig. 7. It is essential to measure the radioactivity of the sample gas within the time (ca. 300s) between (c) and (d) in Fig. 7 since the whole sample gas exists in the effective 


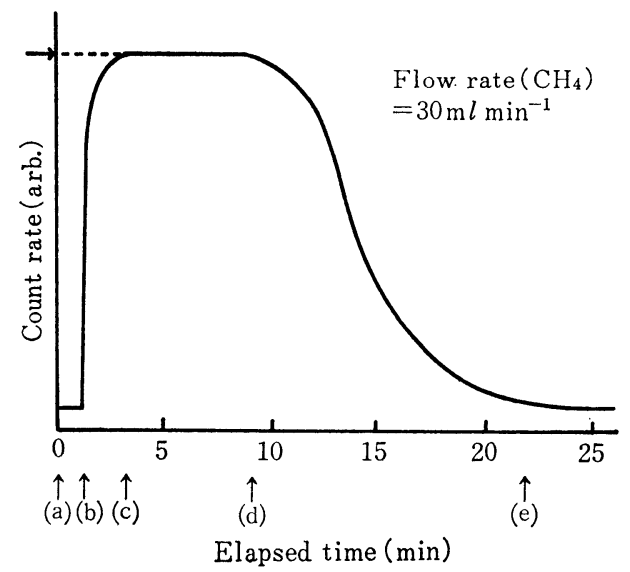

Sample gas started to flow toward the counter at (a), reached the inlet of the tube at (b), entered in the tube completely at (c), reached the outlet at (d), and went out of the tube entirely at (e). Fig. 7 Response curve of tritium measurement obtained ${ }^{\square}$ by using a long-path proportional counter.

volume during this time. The constancy of count rate indicates that the end effect of the counter was avoided, and this was confirmed by using a position sensitive detecting system ${ }^{\text {7), }}$ ). Though a small correction for wall effect should be necessary, the radioactivity of the sample gas could be determined without end effect. Tritiated gas of 1 to $10 \mathrm{ml}$ of less than $10^{4} \mathrm{~Bq}$ could be measured by using this setup. The statistic error was below $1.0 \% \quad(3 \sigma)$ when tritiated gas of 30 to $10^{4} \mathrm{~Bq} \mathrm{~m}^{-1}$ in radioactive concentration was measured. The systematic error consisting of wall effect, sampling, threshold, and dead time was $\pm 2.5 \%$. The overall error was then estimated to be $\pm 3.5 \%$. This method of measurement will be reported in detail elsewhere".

\section{Conclusion}

Radiochemically pure tritiated methane was synthesized by the reaction of tritiated water with aluminum carbide at ca. $470^{\circ} \mathrm{C}$. The prepared gas was filled in two types of containers; a metal cylinder and a glass ampoule, and standardized by the use of a long-path proportional counter with an overall error of $3.5 \%$ $(3 \sigma)$. For the case of ampoule-sealed samples, a small error may arise in the course of sealing procedure, but this type of sample is easy to handle in the calibration work of radioactivity detectors.

\section{Acknowledgment}

The authors are grateful to Mr. M. Kato of their laboratory for a generous gift of tritiated water samples and to Mr. T. Genka for his help in the preparation of this paper.

\section{References}

1) Yoshida, M., et al.: Hoken Butsuri, 18, 217-23 (1983), in Japanese

2) Kushita, K. and Hoizumi, K.: The 20th Annual Meeting on Radioisotopes in the Physical Sciences and Industry, 4p-II-5 (1983), in Japanese

3) Hoizumi, K. and Takeuchi, N.: The 19th Annual Meeting on Radioisotopes in the Physical Science and Industry, 7p-I-11 (1982), in Japanese

4) Abe, T., et al.: Proc. Tritium Technology in Fission, Fusion and Isotopic Applications, Dayton, Ohio, CONF-800427, pp. 367-71 (1980)

5) Ciranni, G. and Guarino, A.:J. Labelled Compounds, II-2, 198-202 (1966)

6) Cacace, F. and Shüller, M.: ibid., XI-3, 313-24 (1975)

7) Matoba, M., et al.: Nucl. Instrum. Methods, 165, 469 (1979)

8) Hoizumi, K. and Takeuchi, N.: The 20th Annual Meeting on Radioisotopes in the Physical Science and Industry, 6p-II-11 (1983), in Japanese

9) to be published 
要旨

\title{
トリチウム標識メタンを用いたトリチウム標準ガスの作製
}

\author{
櫛田浩平，竹内紀男，保泉 澄 \\ 日本原子力研究所アイソトープ事業部 \\ 319-11 茨城県那珂郡東海村
}

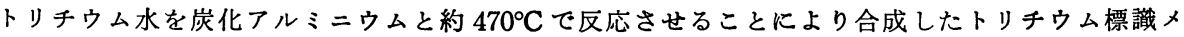
タンを用いて，放射能検出器校正用トリチウム標準ガスを作製した。得られたガスの放射能值の絶 対測定は長径路比例計数管を用いて行った。この計数管により $10^{4} \mathrm{~Bq}$ 以下のトリチウム化ガスを $\pm 3.5 \%(3 \sigma)$ 以内の誤差で值付けすることができる。最終的に，ボンべ型およびアンプル型の 2 種 類の標準ガスを作製した。とくに後者は校正用ガスとして簡便に使用することができる。
\end{abstract}

